\title{
PENGARUH PENERAPAN INFORMASI AKUNTANSI MANAJEMEN TERHADAP KINERJA MANAJERIAL HOTEL DI KOTA KENDARI
}

\author{
Oleh \\ Safaruddin $^{1}$, Ishak Awaluddin ${ }^{2}$, Riswan $^{3}$ \\ Jurusan Akuntansi Fakultas Ekonomi dan Bisnis Universitas Halu Oleo Kendari \\ Sulawesi Tenggara
}

\begin{abstract}
ABSTRAK
Penelitian ini bertujuan untuk mengetahui dan menganalisis pengaruh penerapan informasi akuntansi terhadap kinerja manajerial hotel di kota kendari. Data yang digunakan adalah data primer dan sekunder. Jenis Data yang digunakan adalah data kualitatif dan data kuantitatif. Sampel penelitian yaitu 52 manajer hotel di Kota Kendari. Alat analisis yang digunakan dalam penelitian ini adalah regresi linier sederhana. Hasil penelitian ini menunjukkan bahwa penerapan informasi akuntansi manajemen berpengaruh signifikan terhadap kinerja manajerial. Artinya semakin baik penerapan informasi akuntansi manajemen maka semakin baik pula kinerja manajerial yang ada di hotel kota kendari.
\end{abstract}

Kata kunci : Informasi Akuntansi Manajemen, Kinerja Manajerial

\section{ABSTRACT}

This study aims to determine and analyze the effect of the application of accounting information on hotel managerial performance in the city of Kendari. The data used are primary and secondary data. The type of data used is qualitative data and quantitative data. The analytical tool used in this study is simple linear regression. The results of this study indicate that the application of management accounting information significantly influences managerial performance. This means that the better the application of management accounting information, the better the managerial performance in the hotel town of Kendari.

Keywords: Management Accounting Information, Managerial Performance

\section{PENDAHULUAN}

Pada era globalisasi dengan kemajuan teknologi yang berkembang saat ini persaingan bisnis yang sangat ketat menuntut perusahaan untuk menggunakan kompetensi yang ada dengan semaksimal mungkin, agar dapat memenangkan persaingan dimulai dari kemampuannya memperoleh informasi yang tepat dan akurat. Bagi manajemen, informasi merupakan sarana yang sangat penting untuk membantu mengembangkan kegiatan perusahaan. Kelangsungan hidup dan pertumbuhan suatu perusahaan tergantung pada sistem informasi akuntansi manajemen. Manajemen akan sangat terbantu dengan penggunaan informasi akuntansi yang baik dan akan membantu pihak manajemen dalam pengambilan keputusan yang efektif. Sehingga meminimalisir ketidakpastian dan mengurangi resiko dalam memilih alternatif.

Informasi khususnya sistem informasi diperlukan oleh manajemen organisasi atau perusahaan dalam mengambil keputusan yang berkaitan dengan organisasi ataupun perusahaan. Pentingnya informasi karena informasi merupakan hal terpenting yang menentukan keberhasilan dalam pengambilan keputusan dan implementasi strategi organisasi. Keberhasilan pengambilan keputusan dan implementasi strategi organisasi atau perusahaan berkaitan dengan profitabilitas perusahaan, keberlanjutan kehidupan 
perusahaan dan juga peningkatan daya saing perusahaan baik saat ini maupun di masa yang akan datang.

Salah satu peran penting sistem informasi akuntansi manajemen adalah menyediakan informasi bagi orang yang tepat dengan cara yang tepat dan pada saat yang tepat. Informasi berperan meningkatkan kemampuan manajemen untuk memahami keadaan lingkungan sekitarnya dan mengidentifikasikan aktivitas yang relevan. Perencanaan sistem informasi manajemen yang merupakan bagian dari sistem pengendalian organisasi perlu mendapat perhatian karena sistem informasi berguna bagi organisasi-organisasi untuk mengendalikan dan memonitor proses yang memiliki nilai tambah (Mulyadi, 2012;22).

Informasi merefleksikan kebutuhan dari organisasi secara spesifik. Ketika informasi diolah menjadi alat pengambilan keputusan, sistem informasi merupakan mekanisme untuk meyakinkan bahwa informasi tersebut dapat digunakan oleh manajer dalam bentuk yang mereka inginkan dan kapanpun mereka butuhkan. Sistem informasi membantu aktivitas pengambilan keputusan didalam organisasi lebih cepat dan akurat.

Dalam dunia bisnis, informasi merupakan alat yang penting bagi manajemen untuk membantu menggerakkan dan mengembangkan kegiatan perusahaan. Kelangsungan hidup dan pertumbuhan suatu perusahaan tergantung pada sistem informasi akuntansi manajemen (Mulyadi, 2012;22). Dengan menggunakan informasi akuntansi manajemen, maka akan akan membantu manajemen dalam pengambilan keputusan secara efektif, mengurangi ketidakpastian dan mengurangi resiko dalam memilih alternatif. Dengan menggunakan informasi manajemen ini, bisa dilakukan pengendalian manajemen. Hal ini disebabkan informasi akuntansi manajemen menekankan hubungan antara informasi keuangan dengan manajer yang bertanggung jawab terhadap perencanaan dan pelaksanaannya.

Informasi yang diperlukan oleh manajemen perusahaan dalam pengambilan keputusan dapat dibagi menjadi informasi kuantitatif dan informasi non kuantitatif (Mulyadi, 2012;23). Informasi kuantitatif dibagi lagi menjadi informasi akuntansi dan informasi non akuntansi. Informasi akuntansi terdiri dari informasi operasi, informasi akuntansi keuangan dan informasi akuntansi manajemen. Umunya informasi kuantitatif lebih berperan dalam mengurangi ketidakpastian bila dibandingkan informasi non kuantitatif. Informasi akuntansi manajemen menekankan hubungan antara informasi keuangan dengan manajer yang bertanggung jawab terhadap perencanaan dan pelaksanaannya. Dalam melaksanakan dua fungsi tersebut, maka aktivitas dalam perencanaan dan pengendalian memerlukan beraneka bentuk informasi, dalam bentuk laporan keuangan atau sejenisnya, berupa laporan rutin (terstruktur) dan laporan tidak rutin (tidak terstruktur). Umumnya informasi akuntansi manajemen berwujud laporan yang frekuensi penerbitannya tergantung dari kebutuhan manajemen. Laporan rutin biasanya berisi informasi akuntansi manajemen puncak yang diterbitkan secara bulanan dan kumulatifnya, tiga bulanan, tengah tahunan, dan tahunan. Sedangkan laporan tidak rutin berisi informasi akuntansi manajemen yang dibuat secara insidentil umumnya berupa analisis dan model-model pengambil keputusan.

Berdasarkan pendapat diatas dapat disimpulkan bahwa pada umumnya informasi akuntansi manajemen berwujud laporan yang frekuensi penerbitannya tergantung dari kebutuhan manajemen. Laporan tersebut dapat di kelompokan menjadi laporan rutin dan laporan tidak rutin. Laporan yang di hasilkan tersebut berupa laporan-laporan yang harus dapat dipertanggung jawabkan oleh manajemen. Laporan rutin berisi informasi akuntansi manajemen untuk manajemen puncak yang diterbitkan secara bualanan dan kumulatifnya, tiga bulanan, tengah tahunan, dan tahunan. Sedangkan laporan tidak rutin berisi informasi akuntansi manajemen yang dibuat secara insendentil umumnya berupa analisis dan modelmodel pengambil keputusan. 
Persaingan bisnis yang semakin meningkat menuntut perusahaan untuk memanfaatkan kemampuan yang ada semaksimal mungkin dan meningkatkan efektifitas dalam pengelolaan manajemen. Hal ini dimaksudkan agar perusahaan unggul dalam persaingan dan mampu bersaing dalam situasi dan kondisi persaingan yang semakin ketat dimasa sekarang maupun dimasa yang akan datang. Keunggulan daya saing yang dapat diciptakan oleh perusahaan dapat dicapai dengan salah satu cara yaitu meningkatkan kinerja manajerial.

Kinerja manajerial merupakan hasil kerja secara kualitas dan kuantitas yang dicapai oleh seseorang manajer dalam melaksanakan tugasnya sesuai dengan tanggung jawab yang diberikan kepadanya. Hansen dan Mowen (2009;43), berpendapat bahwa kinerja manajerial merupakan hasil dan keluaran yang dihasilkan oleh manajer sesuai dengan perannya dalam organisasi dalam suatu periode tertentu. Pada umumnya keberhasilan suatu perusahaan banyak tergantung pada faktor-faktor manajerial.

Kemampuan manajer dalam mengelola perusahaan merupakan barometer bagi pertumbuhan perusahaan. Penggunaan teknologi informasi merupakan salah satu cara untuk memudahkan pengelolaan perusahaan. Seorang manajer dikatakan memiliki prestasi dan kinerja yang bagus apabila telah banyak menghasilkan laba bagi perusahaan. Dalam dunia bisnis, informasi merupakan alat yang penting bagi manajemen untuk membantu menggerakkan dan mengembangkan kegiatan perusahaan. Kelangsungan hidup dan pertumbuhan suatu perusahaan tergantung pada sistem informasi yang digunakan.

Fadliah (2014) melakukan penelitian tentang pengaruh penerapan informasi akuntansi manjemen terhadap kinerja manajerial. Pada penelitian ini ia meneliti 23 perusahaan bank pembangunan yang ada di Sumatera Selatan. Sebagai pengukuran dipakai variabel penerapan informasi akuntansi manjemen yaitu laporan rutin dan laporan tidak ritun. Hasil penelitian ini menunjukkan bahwa penerapan pengukuran tersebut berpengaruh terhadap kinerja manajerial. Selanjutnya, Rahayu (2015) melakukan penelitian tentang pengaruh penerapan informasi akuntansi manjemen terhadap kinerja manajerial. Pada penelitian ini ia meneliti 55 perusahaan manufaktur bersakala besar di Kawasan Industri Medan yang ada di Sumatera Utara. Sebagai pengukuran dipakai variabel penerapan informasi akuntansi manjemen yaitu laporan rutin, laporan tidak rutin. Hasil penelitian ini menunjukkan bahwa penerapan pengukuran tersebut berpengaruh terhadap kinerja manajerial.

Pemilihan hotel bintang tiga, empat dan lima dikarenakan pada umumnya sudah menerapkan dan menggunakan informasi akuntansi manajemen dalam pengelolaan perusahaannya, dan umumnya sudah dikelola secara professional sesuai dengan standar perhotelan. Selain itu aspek-aspek kinerja non keuangan sudah tercakup dalam aktivitas perusahaan. Selain berbeda pada subjek (responden) penelitian, peneltian ini juga menggunakan kuisioner yang berbeda dengan penelitian sebelumnya. Penelitian ini mengarahkan pertanyaan-pertanyaan pada penggunaan informasi oleh manajer puncak hotel bintang tiga, empat dan lima dan evaluasi kinerja manajerial dengan tolak ukur non financial, sedangkan penelitian terdahulu lebih mengarahkan pada konsistensi penyusunan laporan-laporan baik rutin maupun tidak rutin dengan kinerja keuangan.

Berdasarkan hasil-hasil yang telah dicapai oleh penelitian-penelitian sebelumnya, maka peneliti tertarik untuk membuktikan adanya pengaruh informasi akuntansi manajemen dengan kinerja manajerial dengan judul penelitian yaitu "Pengaruh Penerapan Informasi Akuntansi Manajemen Terhadap Kinerja Manajerial Hotel Di Kota Kendari". Tujuan penelitian ini adalah untuk mengetahui dan menganalisis penerapan informasi akuntansi manajemen berpengaruh signifikan terhadap kinerja manajerial hotel di Kota Kendari. 


\section{Manfaat Penelitian}

Penelitian ini diharapkan dapat bermanfaat bagi pihak-pihak yang berkepentingan sebagai berikut: bagi hotel di Kota Kendari, dengan adanya penelitian ini, dapat memberikan masukan bagi Hotel Di Kota Kendari tentang pengaruh penerapan informasi akuntansi manajemen terhadap kinerja manajerial. Bagi peneliti, untuk menambah dan memperdalam wawasan serta pengetahuan peneliti tentang pengaruh penerapan informasi akuntansi manajemen terhadap kinerja manajerial. Bagi Peneliti Selanjutnya, penelitian ini diharapkan dapat menambah pengetahuan dan pemahaman serta nantinya dapat dijadikan sebagai salah satu bahan referensi pengetahuan, bahan diskusi, dan bahan kajian lanjutan bagi pembaca tentang masalah yang berkaitan dengan pengaruh penerapan informasi akuntansi manajemen terhadap kinerja manajerial.

\section{Ruang Lingkup Penelitian}

Untuk menghindari adanya penafsiran yang berbeda dan untuk terarahnya penelitian ini, maka penulis membatasi ruang lingkup penelitian yakni pengaruh penerapan informasi akuntansi manajemen terhadap kinerja manajerial Hotel di Kota Kendari.

\section{Pengertian Akuntansi Manajemen}

\section{TINJAUAN PUSTAKA}

Akuntansi manajemen timbul karena akibat adanya kebutuhan akan informasi akuntansi yang dapat membantu manajemen dalam memimpin suatu perusahaan yang semakin besar dan semakin kompleks. Akuntansi manajemen merupakan suatu sistem informasi yang mana dengan informasi ini manajemen dapat mengambil keputusankeputusan dalam hal memimpin selia mengendalikan kegiatan-kegiatan perusahaan. Seorang manajer harus dapat menjabarkan teori manajemen dan teori-teori lainnya dalam bentuk angka-angka yang nyata, sehingga manajemen dapat menganalisa dan menginterprestasikan angka-angka tersebut dalam rangka pengambilan keputusan. Akuntansi manajemen adalah suatu profesi yang melibatkan kemitraan dalam pengambilan keputusan manajemen, menyusun perencanaan dan sistem manajemen kinerja, serta menyediakan keahlian dalam pelaporan keuangan dan pengendalian untuk membantu manajemen dalam memformulasikan dan mengimplementasikan suatu strategi organisasi.

Simamora (2012:13) mengatakan bahwa akuntansi manajemen adalah proses pengidentifikasian, pengukuran penghimpunan, penganalisaan, penyusunan, penafsiran dan pengkomunikasian informasi keuangan yang digunakan oleh manajemen untuk merencanakan, mengevaluasi dan mengendalikan kegiatan usaha di dalam sebuah organisasi, serta untuk memastikan penggunaan dan akuntabilitas sumber daya yang tepat.

Siregar, Suripto, dkk $(2013 ; 21)$ mendefinisikan bahwa akuntansi manajemen adalah proses mengidentifikasi, mengukur, mengakumulasi, menyiapkan, menganalisis, menginterpretasikan, dan mengomunikasikan kejadian ekonomi yang digunakan oleh manajemen untuk melakukan perencanaan, pengendalian, pengambilan keputusan dan penilaian kinerja dalam organisasi.

Hansen dan Mowen $(2009 ; 14)$ mengatakan bahwa akuntansi manajemen adalah proses mengidenfitikasi, mengumpulkan, mengukur, mengklasifikasi dan melaporkan informasi yang bermanfaat bagi pengguna internal dalam merencanakan, mengendalikan dan mengambil keputusan.

Berdasakan pengertian diatas dapat ditarik kesimpulan bahwa akuntansi manajemen sebagai suatu proses pengolahan informasi untuk memenuhi semua kebutuhan manajemen dalam menjalankan fungsi dari sebuah perencanaan, pengkoordinasian dan juga pengendalian perusahaan atau organisasi. 


\section{Pengertian Informasi Akuntansi Manajemen}

Informasi akuntansi manajemen diperlukan oleh manajemen untuk melaksanakan dua fungsi pokok manajemen yakni perencanaan dan pengendalian aktivitas perusahaan. Informasi akuntansi manajemen ini dihasilkan oleh sistem pengolahan informasi keuangan yang disebut akuntansi manajemen. Informasi akuntansi manajemen dibutuhkan oleh manajemen dalam berbagai jenjang organisasi untuk menyusun rencana aktivitas perusahaan di masa yang akan datang.

Peran utama dari informasi akuntansi manajemen adalah menyediakan informasi yang memudahkan proses pengambilan keputusan. Informasi akuntansi manajemen sebagai salah satu produk sistem informasi akuntansi manajemen berperan dalam membantu memprediksi konsekuensi yang mungkin terjadi atas berbagai alternatif tindakan yang dapat dilakukan pada berbagai aktivitas seperti perencanaan, pengendalian, dan pengambilan keputusan.

Informasi akuntansi manajemen adalah informasi formal yang bersifat keuangan dan non keuangan, kuantitatif dan kualitatif, rutin dan tidak rutin. Informasi formal adalah informasi yang terstruktur dan yang tidak terstruktur. Informasi yang terstruktur adalah laporan-laporan yang diterbitkan oleh suatu sistem informasi di perusahaan itu sendiri. Informasi yang terstruktur biasanya diterbitkan secara rutin sedangkan informasi yang tidak terstruktur hanya sekali-kali terbit jika diperlukan (tidak rutin).

Informasi akuntansi manajemen ini disajikan kepada manajemen perusahaan dalam berbagai laporan keuangan seperti, Anggaran, Laporan penjualan, Laporan biaya produksi, Laporan biaya menurut pusat pertanggung jawaban, Laporan biaya menurut aktivitas, Laporan biaya pemasaran

Informasi akuntansi manajemen di butuhkan oleh manajemen berbagai jenjang organisasi untuk menyusun rencana aktivitas perusahaan dimasa yang akan datang. Informasi akuntansi manajemen sangat bermanfaat bagi manajemen terutama pada tahap analisis konsekuensi setiap alternatif tindakan yang mungkin dalam proses pengambilan keputusan. Hal ini memungkinkan manajemen melakukan pengambilan keputusan untuk memilih alternatif tindakan yang terbaik diantara alternatif tindakan yang dipertimbangkan. Salah satu tujuan dari sistem akuntansi manajemen adalah untuk menyediakan informasi yang digunakan dalam perencaaan, pengendalian, dan pengevaluasian. Tujuan ini mengunkapkan bahwa manajer dan pengguna lainnya membutuhkan Informasi Akuntansi Manajemen dan perlu mengetahui bagaimana cara menggunakannya. Hansen dan Mowen $(2009 ; 14)$ menyatakan bahwa informasi akuntansi manajemen dapat membantu manajer mengidentifikasi suatu masalah, menyelesaikan masalah, dan mengevaluasi kinerja (informasi akuntansi dibuthkan dan digunakan dalam semua lingkup manajemen, meliputi perencanaan, pengendalian dan pengambilan keputusan).

Informasi Akuntansi manajemen dapat dihubungkan dengan tiga hal: objek informasi, alternatif yang dipilih, dan wewenang manajer.

1. Jika informasi akuntansi manajemen di hubungkan dengan objek informasi seperti produk, departemen, atau aktivitas maka akan dihasilkan konsep informasi akuntansi penuh.

2. Jika informasi akuntansi manajemen dihubungkan dengan alternatif yang akan dipilih, maka akan dihasilkan konsep informasi akuntansi diferensial, yang sangat diperlukan oleh manajemen dalam pengambilan keputusan pemilihan alternatif. 
3. Jika informasi akuntansi manajemen dihubungkan dengan wewenang manajer, dihasilakn konsep informasi akuntansi pertanggungjawaban, yang terutama bermanfaat untuk mempengaruhi perilaku manusia dalam organisasi.

\section{Pengetian Kinerja Manajerial}

Kinerja sebagai suatu gambaran pencapaian pelaksanaan suatu kegiatan, program, kebijaksanaan dalam mewujudkan sasaran, tujuan, misi, dan visi organisasi. Secara umum, kinerja merupakan prestasi yang dicapai oleh organisasi dalam periode tertentu. Kinerja manajerial adalah ukuran seberapa efektif dan efesien manajer telah bekerja untuk mencapai tujuan organisasi.

Mulyadi (2012;43) kinerja manajerial merupakan suatu kinerja yang dihasilkan oleh seorang manajer dengan mengerahkan bakat dan kemampuan serta usaha beberapa orang lain yang berada di dalam daerah wewenangnya.

Wibowo (2011;32) kinerja manajerial adalah gambaran mengenai tingkat pencapaian pelaksanaan suatu kegiatan, program, kebijaksanaan dalam mewujudkan sasaran, tujuan, misi, visi organisasi yang tertuang dalam perumusan skema strategi suatu organisasi.

Berdasarkan pengertian di atas, dapat disimpulkan bahwa kinerja manajerial adalah sebagai efektivitas yang ditetapkan dari setiap kelompok yang berkenaan dengan usahausaha yang sistematik dan meningkatkan kemampuan organisasi secara terus menerus mencapai kebutuhannya secara efektif.

\section{Dimensi Kinerja Manajerial}

Silalahi (2011:40) Dimensi untuk mengukur penilaian kinerja manajerial meliputi delapan dimensi aktivitas manajerial, yaitu:

1) Perencanaan (Planning), aktivitas perencanaan yang dimaksud adalah kemampuan dalam menentukan kebijakan dari sekumpulan kegiatan, untuk selanjutnya dilaksanakan dengan mempertimbangkan kondisi waktu sekarang dan yang akan datang. Perencanaan bertujuan untuk memberikan pedoman dan tata cara pelaksanaan tujuan, kebijakan, penganggaran, dan program kerja sehingga terlaksana sesuai dengan sasaran yang telah ditetapkan.

2) Investigasi (Investigating), aktivitas investigasi yang dimaksud adalah kemampuan dalam mengumpulkan dan menyiapkan informasi untuk catatan, laporan dan rekening, mengukur hasil, menentukan persediaan, serta analisis pekerjaan.

3) Koordinasi (Coordinating), aktivitas koordinasi yang dimaksud adalah kemampuan dalam tukar menukar informasi dengan orang di bagian organisasi lain untuk mengaitkan dan menyesuaikan program, memberitahukan kepada bagian lain, dan hubungannya dengan manajer lain.

4) Evaluasi (Evaluating), aktivitas evaluasi yang dimaksud adalah kemampuan dalam menilai dan mengukur proposal, kinerja yang diamati atau dilaporkan yang meliputi penilaian pegawai, penilaian catatan hasil, penilaian laporan keuangan, dan pemeriksaan produk.

5) Pengawasan (Supervising), aktivitas pengawasan yang dimaksud adalah kemampuan dalam memberikan pengarahan, membimbing, melatih, memimpin dan mengembangkan bawahan serta menjelaskan peraturan pada bawahan, menjelaskan tujuan kerja dan menangani keluhan pegawai.

6) Pemilihan staf (Staffing), aktivitas pemilihan staf yang dimaksud adalah kemampuan untuk mempertahankan angkatan kerja yang ada pada bagian anda, melakukan 
perekrutan pegawai, mewawancarai mereka, memilih pegawai baru, menempatkan pada bagian yang sesuai, mempromosikan dan memutasikan pegawai.

7) Negosiasi (Negotiating), aktivitas negosiasi yang dimaksud adalah kemampuan dalam melakukan pembelian, penjualan atau melakukan kontrak untuk barang dan jasa, menghubungi pemasok, dan melakukan tawar menawar dengan penjual, serta tawar menawar secara kelompok.

8) Perwakilan (Representating), aktivitas representasi yang dimaksud adalah kemampuan dalam menghadiri pertemuan-pertemuan dengan perusahaan lain, pertemuan dengan perkumpulan bisnis, perwakilan dari organisasi, pidato untuk acara-acara kemasyarakatan, pendekatan ke masyarakat, serta kemampuan dalam mempromosikan tujuan utama perusahaan.

\section{Penelitian Terdahulu}

Penelitian oleh Ahmad Pamungkas dengan judul Pengaruh Penggunaan Informasi Akuntansi Manajemen Terhadap Kinerja Manajerial Pada Hotel Bintang Tiga, Empat Dan Lima Di Kota Jakarta Pusat. Hasil penelitian menunjukan bahwa frekuensi penerbitan laporan rutin dan frekuensi laporan tidak rutin berpengaruh signifikan terhadap kinerja manajerial di Hotel bintang tiga, empat dan lima di Kota Jakarta Pusat. Persamaan penelitian ini dengan penelitian Ahmad Pamungkas adalah sama-sama meneliti tentang informasi akuntansi manajemen dan kinerja manajerial. Adapun perbedaannya yaitu tempat penelitian, dimana tempat penelitian ini yaitu Hotel di Kota Kendari sedangkan tempat penelitian Ahmad Pamungkas yaitu pada Hotel Bintang Tiga, Empat Dan Lima Di Kota Jakarta Pusat.

Penelitian oleh Indah Suryani dengan judul Pengaruh Penggunaan Informasi Akuntansi Manajemen dan Desentralisasi Terhadap Kinerja Manajerial (Survey pada Dealer Mobil Kota Jambi). Hasil penelitian menunjukan bahwa frekuensi penerbitan laporan rutin, frekuensi penerbitan laporan tidak rutin, kualitas informasi akuntansi manajemen dan desentralisasi secara simultan berpengaruh terhadapkinerja manajerial di main dealer mobil di Kota Jambi. Secara parsial, frekuensi penerbitan laporan tidak rutin tidak berpengaruh signifikan terhadap kinerja manajerial. Secara keseluruhan, pengaruh pengunaan informasi akuntansi manajemen dan desentralisasi terhadap kinerja manajerial adalah sebesar $61 \%$, sedangkan $39 \%$ sisanya dipengaruhi oleh variabel lain diluar variabel yang diteliti. Persamaan penelitian ini dengan penelitian Indah Suryani adalah sama-sama meneliti tentang informasi akuntansi manajemen dan kinerja manajerial. Adapun perbedaannya yaitu tempat penelitian, dimana tempat penelitian ini yaitu d Hotel di Kota Kendari sedangkan tempat penelitian Indah Suryani yaitu di Dealer Mobil Kota Jambi.

Penelitian oleh Rahayu dengan judul pengaruh pengaruh penerapan informasi akuntansi manjemen terhadap kinerja manajerial (pada Bank Pembangunan Daerah di Sumatera Selatan). Hasil penelitian menunjukan bahwa frekuensi penerbitan laporan rutin dan frekuensi penerbitan laporan tidak rutin berpengaruh signifikan terhadap kinerja manajerial baik secara parsial maupun simultan. Persamaan penelitian ini dengan penelitian Rahayu adalah sama-sama meneliti tentang informasi akuntansi manajemen dan kinerja manajerial. Adapun perbedaannya yaitu tempat penelitian, dimana tempat penelitian ini yaitu Hotel di Kota Kendari sedangkan tempat penelitian Rahayu yaitu di Bank Pembangunan Daerah di Sumatera Selatan.

Penelitian oleh Fadliah dengan judul pengaruh penerapan informasi akuntansi manjemen terhadap kinerja manajerial pada perusahaan manufaktur bersakala besar di Kawasan Industri Medan. Hasil penelitian menunjukan bahwa frekuensi penerbitan laporan rutin dan frekuensi penerbitan laporan tidak rutin berpengaruh signifikan terhadap kinerja 
manajerial baik secara parsial maupun simultan. Persamaan penelitian ini dengan penelitian Fadliah adalah sama-sama meneliti tentang rentabilitas ekonomis. Adapun perbedaannya yaitu tempat penelitian, dimana tempat penelitian ini yaitu Hotel di Kota Kendari sedangkan tempat penelitian Fadliah yaitu pada perusahaan manufaktur bersakala besar di Kawasan Industri Medan.

\section{Kerangka Pikir}

Informasi akuntansi manajemen diperlukan oleh manajemen untuk melaksanakan dua fungsi pokok manajemen yakni perencanaan dan pengendalian aktivitas perusahaan. Informasi akuntansi manajemen ini dihasilkan oleh sistem pengolahan informasi keuangan yang disebut akuntansi manajemen. Informasi akuntansi manajemen dibutuhkan oleh manajemen dalam berbagai jenjang organisasi untuk menyusun rencana aktivitas perusahaan di masa yang akan datang.

Informasi yang diperlukan oleh manajemen perusahaan dalam pengambilan keputusan dapat dibagi menjadi informasi kuantitatif dan informasi non kuantitatif (Mulyadi, 2012). Informasi kuantitatif dibagi lagi menjadi informasi akuntansi dan informasi non akuntansi. Informasi akuntansi terdiri dari informasi operasi, informasi akuntansi keuangan dan informasi akuntansi manajemen. Umunya informasi kuantitatif lebih berperan dalam mengurangi ketidakpastian bila dibandingkan informasi non kuantitatif. Informasi akuntansi manajemen menekankan hubungan antara informasi keuangan dengan manajer yang bertanggung jawab terhadap perencanaan dan pelaksanaannya. Dalam melaksanakan dua fungsi tersebut, maka aktivitas dalam perencanaan dan pengendalian memerlukan beraneka bentuk informasi, dalam bentuk laporan keuangan atau sejenisnya, berupa laporan rutin (terstruktur) dan laporan tidak rutin (tidak terstruktur). Umumnya informasi akuntansi manajemen berwujud laporan yang frekuensi penerbitannya tergantung dari kebutuhan manajemen. Laporan rutin biasanya berisi informasi akuntansi manajemen puncak yang diterbitkan secara bulanan dan kumulatifnya, tiga bulanan, tengah tahunan, dan tahunan. Sedangkan laporan tidak rutin berisi informasi akuntansi manajemen yang dibuat secara insidentil umumnya berupa analisis dan model-model pengambil keputusan.

Kinerja manajerial merupakan hasil kerja secara kualitas dan kuantitas yang dicapai oleh seseorang manajer dalam melaksanakan tugasnya sesuai dengan tanggung jawab yang diberikan kepadanya. Ingkiriwang (2013), berpendapat bahwa kinerja manajerial merupakan hasil dan keluaran yang dihasilkan oleh manajer sesuai dengan perannya dalam organisasi dalam suatu periode tertentu. Pada umumnya keberhasilan suatu perusahaan banyak tergantung pada faktor-faktor manajerial.

Kemampuan manajer dalam mengelola perusahaan merupakan barometer bagi pertumbuhan perusahaan. Penggunaan teknologi informasi merupakan salah satu cara untuk memudahkan pengelolaan perusahaan. Seorang manajer dikatakan memiliki prestasi dan kinerja yang bagus apabila telah banyak menghasilkan laba bagi perusahaan. Dalam dunia bisnis, informasi merupakan alat yang penting bagi manajemen untuk membantu menggerakkan dan mengembangkan kegiatan perusahaan. Kelangsungan hidup dan pertumbuhan suatu perusahaan tergantung pada sistem informasi yang digunakan.

\section{Hipotesis Penelitian}

Perumusan hipotesis yang diajukan dalam penelitian ini bertujuan untuk menguji pengaruh informasi akuntansi manajemen terhadap kinerja manajerial. Adapun hipotesis dalam penelitian adalah sebagai berikut :

H1 : Penerapan informasi akuntansi manajemen berpengaruh signifikan terhadap kinerja manajerial hotel di Kota Kendari. 


\section{Lokasi Dan Objek Penelitian}

\section{METODE PENELITIAN}

Lokasi penelitian adalah tempat dimana penelitian dilakukan untuk mempereloh data atau informasi yang diperlukan. Lokasi ini bisa di wilayah atau suatu lembaga tertentu dalam masyarakat. Untuk memperoleh data primer, lokasi penelitian dilakukan pada hotel yang berada di kota Kendari Provinsi Sulawesi Tenggara. Objek dalam penelitian ini adalah untuk mengetahui pengaruh variabel independen yaitu informasi akuntansi manajemen (X) terhadap variabel dependen yaitu kinerja manajerial (Y) pada hotel di Kota Kendari.

\section{Populasi Dan Sampel}

Populasi adalah wilayah generalisasi yang terdiri atas objek/subjek yang mempunyai kuantitas dan karakteristik tertentu yang ditetapkan oleh peneliti untuk dipelajari dan kemudian ditarik kesimpulannya (Sugiyono, 2015;36). Populasi dalam penelitian ini adalah seluruh manajer hotel di Kota Kendari yaitu sebanyak 141 manajer hotel.

Sampel adalah bagian dari jumlah dan karakteristik yang dimiliki oleh populasi tersebut (Sugiyono, 2015;36). Teknik sampling yang digunakan dalam penelitian ini adalah purposive sampling. Sampling Purposive adalah teknik penentuan sampel dengan pertimbangan tertentu (Sugiono, 2015;36). Kriteria yang melandasi pemilihan sampel adalah sebagai berikut :

1) Hotel yang berada di kota Kendari Provinsi Sulawesi Temggara.

2) Seluruh manajer hotel bintang 3 dan 4 di kota Kendari.

Tabel 3.1

Daftar Sampel

\begin{tabular}{|c|l|c|c|}
\hline No & \multicolumn{1}{|c|}{ Nama Hotel } & Bintang & $\begin{array}{c}\text { Jumlah Manajer } \\
\text { Hotel }\end{array}$ \\
\hline 1 & Hotel Claro & 4 & 6 \\
\hline 2 & Swissbell Hotel Kendari & 4 & 6 \\
\hline 3 & Plaza Inn & 3 & 5 \\
\hline 4 & Imperial & 3 & 5 \\
\hline 5 & Same & 3 & 5 \\
\hline 6 & Horison & 3 & 5 \\
\hline 7 & Zahra Syariah & 3 & 5 \\
\hline 8 & Zenith & 3 & 5 \\
\hline 9 & Wixel & 3 & 5 \\
\hline 10 & Athaya & 3 & 5 \\
\hline \multicolumn{2}{|c|}{ Jumlah sampel penelitian } \\
\hline
\end{tabular}

Sumber: BPS Provinsi Sulawesi Tenggara Tahun 2019

\section{Jenis dan Sumber Data}

Jenis data yang digunakan dalam penelitian ini adalah:

1. Data kualitatif adalah data yang tidak dapat diukur dalam skala numerik atau angkaangka (Sujarweni, 2015;27). Data kualitatif dalam penelitian ini berupa uraian penjelasan dari variabel dan objek penelitian dan juga pertanyaan dalam kuesioner yang akan diklasifikasikan kedalam kategori menggunakan skala ordinal dan skala likert kepada manajer hotel di Kota Kendari.

2. Data kuantitatif adalah data yang diukur dalam skala numerik (Sujarweni, 2015;27). Data kuantitatif dalam penelitian ini adalah jawaban responden atas pertanyaan kuesioner yang diukur menggunakan skor dari skala likert dan skala ordinal.

Data dalam penelitian ini berasal dari dua sumber, yaitu sebagai berikut:

1. Data primer, yaitu data yang didapat dari subjek penelitian dengan cara melakukan pengamatan, percobaan atau wawancara (Sujarweni, 2015;27). Data dalam penelitian 
ini bersumber langsung dari responden manajer hotel di Kota Kendari yang dikumpulkan melalui kuesioner.

2. Data sekunder, yaitu data yang tidak langsung diperoleh dari sumber pertama dan telah tersusun dalam bentuk dokumen tertulis (Sujarweni, 2015;27). Data sekunder dalam penelitian ini, yaitu mengambil data-data dokumen pada hotel di Kota Kendari yakni profil dan sejarah hotel di Kota Kendari.

\section{Metode Pengumpulan Data}

Dalam penelitian ini tehnik yang digunakan untuk mengumpulkan data adalah:

1. Wawancara, Sugiyono $(2015 ; 36)$ wawancara merupakan pertemuan dua orang untuk bertukar informasi dan ide melalui tanya jawab, sehingga dapat dikontruksikan makna dalam suatu topik tertentu. Adapun wawancara yang dilakukan yaitu terkait dengan informasi akuntansi manajemen yang meliputi frekuensi laporan rutin dan laporan tidak rutin kinerja manajerial terhadap variabel dependen yaitu kinerja manajerial pada hotel di Kota Kendari.

2. Angket atau Kuesioner merupakan tekhnik pengumpulan data yang dilakukan dengan cara memberi seperangkat pertanyaan atau pernyataan tertulis kepada responden untuk dijawab (Sugiyono, 2015;36).

\section{Uji Instrumen Penelitian}

Peneliti melakukan uji instrumen penelitian dari data-data yang akan diolah yaitu Uji Validitas, Uji Reliabilitas.

\section{Metode Analisis Data}

\section{Analisis Deskriptif}

Metode analisis data yang dilakukan adalah metode analisis deskriptif persentase. Statistik deskriptif memberikan gambaran mengenai variabel-variabel penelitian. Berdasarkan data primer yang diperoleh, distribusi frekuensi masing-masing jawaban dikelompokan sesuai dengan item jawaban. Skala yang digunakan untuk menilai pertanyaan adalah skala likert. Nilai rata-rata pembobotan atau nilai skor jawaban responden yang diperoleh diklasifikasi kedalam rentang skala kategori nilai yang disajikan dalam tabel berikut :

Tabel 3.2

Penentuan Kategori Rata-rata Skor Pernyataan Responden

\begin{tabular}{|l|l|l|}
\hline No. & Nilai Rata-rata Skor Jawaban & Makna Kategori/Interpretasi \\
\hline 1. & $1-1,8$ & Sangat Rendah/Tidak baik \\
\hline 2. & $1,8 \leq 2,6$ & Rendah/Kurang baik \\
\hline 3. & $2,6 \leq 3,4$ & Cukup Tinggi/cukup baik \\
\hline 4. & $3,4 \leq 4,2$ & Tinggi/Baik \\
\hline 5. & $\geq 4,22$ & Sangat tinggi/Sangat baik \\
\hline
\end{tabular}

Sumber : Solimun et al 2017.

\section{Analisis Inferensial}

Analisis inferensial dalam penelitian ini dilakukan dengan menggunakan Uji Regresi Linear Sederhana. Sebelum melakukan analisis inferensial terlebih dahulu dilakukan uji prasyarat, yaitu:

\section{Uji Asumsi Klasik}

\section{Uji Heterokedastisitas}

Uji heterokedastistas bertujuan untuk menguji ketidaksamaan varian dari residual suatu pengamatan ke pengamatan lain. Model regresi yang baik adalah regresi yang bebas dari heterokedastisitas atau homoskesdasitas. Uji heterokedastisitas dapat dilakukan dengan melihat grafik scatterplot. Jika gambar dimana titik-titik yang ada pada grafik tersebut tidak membentuk pola tertentu yang jelas dan titik-titik tersebut menyebar diatas 
dan dibawah angka 0 pada sumbu Y, maka tidak terjadi heterokedastisitas. Adanya heterokedastisitas mengindikasikan varians yang tidak konstan menghasilkan model estimator yang bias (Ghozali, 2016;34).

\section{Uji Normalitas}

Model regresi yang baik memiliki distribusi data yang normal atau mendekati normal. Uji normalitas bertujuan menguji apakah dalam model regresi, variabel dependen dan independen keduannya mempunyai distribusi normal atau tidak. Untuk mendeteksi normalitas baik menggunakan kurva persebaran data berupa curve normal dan normal plot dimana bila data menyebar disekitar dan mengikuti garis diagonal maka model regresi memenuhi asumsi normalitas atau menggunakan uji kolmogorov-sminornov, dengan kriteria nilai $\rho$ value $<0,05$ berarti terdistribusi tidak normal (Ghozali, 2016;34).

\section{Uji Autokorelasi}

Uji autokorelasi bertujuan untuk menguji apakah dalam model regresi linear ada korelasi antara kesalahan pengganggu pada periode tdengan kesalahan pengganggu pada periode t-1. Munculnya gejala autokorelasi dalam regresi linear dengan metode Ordinary Least Squares (OLS) akan mengakibatkan melebarnya interval keyakinan sehingga uji signifikansi kurang kuat dan penaksir OLS akan menimbulkan distorsi terhadap nilai parameter sebenarnya. Untuk mengetahui adanya gejala inidalam model analisis regresi yang digunakan, maka harus dilakukan pengujian dengan metode Durbin-Waston, secara umum dapat dilihat patokan bahwa :

a. Angka D-W di bawah -4 berarti ada autokorelasi positif.

b. Angka D-W di bawah -4 sampai +4 , berarti tidak ada autokorelasi.

c. Angka D-W di atas +4 berarti ada autukorelasi negatif.

\section{Pengujian Hipotesis}

Pengujian hipotesis digunakan untuk melihat seberapa besar pengaruh penerapan informasi akuntansi manajemen terhadap kinerja manajerial melalui analisis regresi sederhana, yaitu:

\section{Uji Signifikansi Parameter Individual (Uji Statistik t)}

Uji t bertujuan untuk menguji seberapa jauh pengaruh satu variabel independen secara individual. Untuk dapat mengetahui apakah ada pengaruh yang signifikan dari variabel masing-masing independen terhadap variabel dependen, maka nilai signifikannya dibandingkan dengan derajat kepercayaannya. Menurut (Ghozali, 2016;34) dasar pengambilan keputusan pada uji parsial (uji t) adalah sebagai berikut:

1) Jika nilai $t_{\text {hitung }}>t_{\text {tabel }}$ dan tingkat signifikannya lebih kecil dari 0,05 maka hipotesis diterima, artinya variabel independen berpengaruh signifikan terhadap variabel dependen.

2) Jika nilai $t_{\text {hitung }}<t_{\text {tabel }}$ dan tingkat signifikansi lebih besar dari 0,05 maka hipotesis ditolak. artinya variabel independen tidak berpengaruh signifikan terhadap variabel dependen.

\section{Uji Koefisien Determinasi}

Koefisien determinasi $\left(R^{2}\right)$ pada intinya mengukur seberapa jauh kemampuan model dalam menerangkan variasi variabel dependen. Nilai koefisien determinasi berada diantara nol dan satu. Nilai $\left(R^{2}\right)$ yang kecil berarti kemampuan variabel-variabel independen dalam menjelaskan variabel dependen amat terbatas. Nilai yang mendekati satu berarti variabelvariabel independen memberikan hampir semua informasi yang dibutuhkan untuk memprediksi variabel-variabel dependen. Secara umum koefisien determinasi untuk data silang (crossection) relatif rendah karena adanya variasi yang besar antara masing-masing pengamatan, sedangkan untuk data runtun waktu (time series) biasanya mempunyai nilai koefisien determinasi yang tinggi (Ghozali, 2016;34). 


\section{Metode Analisis Regresi Linear Sederhana}

Siregar (2013) menyatakan analisis regresi linear sederhana digunakan untuk mengetahui pengaruh satu atau lebih variabel bebas (independen) terhadap satu variabel tak bebas (dependen). Alat analisis yang digunakan dalam penelitian ini adalah analisis regresi linear sederhana dengan bantuan software IBM Statistical Package for Social Sciences (SPSS) Statistics Versi 23. Teknik ini digunakan untuk menguji penerapan informasi akuntansi manajemen (X) terhadap kinerja manajerial (Y). Hubungan antara variabel tersebut dapat digambarkan dalam persamaan sebagai berikut:

$\mathrm{Y}=\alpha+\beta \mathrm{X}+\varepsilon$

Keterangan:

Y : Kinerja Manajerial

$\alpha \quad$ : Konstanta

$\beta 1 \ldots \beta n$ : Koefisien arah regresi

$\mathrm{X}_{1} \quad$ : penerapan informasi akuntansi manajemen

$\varepsilon$ (epsilon) : Kesalahan pengganggu

\section{Definisi Operasional Variabel dan Pengukuranya} berikut :

Adapun definisi operasional yang digunakan dalam penelitian ini adalah sebagai

1. Penerapan informasi akuntansi manajemen adalah suatu proses pengolahan informasi untuk memenuhi semua kebutuhan manajemen dalam menjalankan fungsi dari sebuah perencanaan, pengkoordinasian dan juga pengendalian perusahaan atau organisasi. Penerapan informasi akuntansi manajemen diukur dengan indikator antara lain Frekuensi Laporan Rutin dan Frekuensi Laporan Tidak Rutin.

2. Kinerja manajerial adalah sebagai efektivitas yang ditetapkan dari setiap kelompok yang berkenaan dengan usaha-usaha yang sistematik dan meningkatkan kemampuan organisasi secara terus menerus mencapai kebutuhannya secara efektif. Kinerja manajeriaal diukur dengan indikator antara lain Perencanaan, Koordinasi, Investigasi, Pemilihan staf, Negosiasi, Perwakilan , Pengawassan dan Evaluasi.

\section{HASIL DAN PEMBAHASAN}

\section{Hasil Penelitian}

\section{Tingkat Pengembalian Kuesioner}

Berdasarkan hasil jawaban atas kuesioner yang dibagikan kepada responden yakni manajer hotel bintang 3 dan bintang 4 yang berada di kota Kendari berjumlah 52 kuesioner. Adapun tingkat pengembalian kuesioner penelitian ditunjukkan pada tabel berikut ini:

Tabel 4.1

Tingkat pengembalian kuesioner

\begin{tabular}{|l|l|l|l|}
\hline No. & \multicolumn{1}{|c|}{ Uraian } & Jumlah (rangkap) & Persentase (\%) \\
\hline 1. & Kuesioner yang kembali & 43 & 82,69 \\
\hline 2. & Kuesioner yang tidak kembali & 9 & 17,31 \\
\hline 3. & Kuesioner yang disebar & 52 & 100 \\
\hline
\end{tabular}

Sumber: Data hasil pengembalian kuisioner tahun 2019

Tabel 4.1 di atas menunjukkan bahwa persentase kuesioner yang kembali adalah sebesar 82,69\% atau 43 kuesioner sedangkan kuesioner yang tidak kembali sebesar 17,31\% atau 9 kuesioner dari total kuesioner yang dibagikan sebanyak 52 kuesioner. Adapun kuesioner yang tidak kembali, dikarena ada beberapa manajer hotel berada di luar kota. 


\section{Karakteristik Responden}

Karakteristik responden dapat diklasifikasikan berdasarkan jenis kelamin dan usia. Sebanyak 52 kuesioner yang disebarkan kepada responden dan 43 kuesioner yang dikembalikan serta dapat dianalisis. Dengan demikian tingkat pengembalian kuesioner responden yang diperoleh adalah $82,69 \%$. Adapun gambaran mengenai responden pada penelitian ini adalah sebagai berikut:

\section{Karakteristik Responden Berdasarkan Usia}

Berdasarkan 43 kuesioner yang diperoleh dari responden, maka diperoleh gambaran umum tentang jumlah responden berdasarkan usia. Hasil penelitian menunjukkan bahwa 43 manajer hotel bintang 3 dan bintang 4 yang berada di kota Kendari yang menjadi responden dalam penelitian ini, menunjukkan bahwa mayoritas responden berada pada usia 31-40 tahun yaitu sebanyak 27 orang dengan tingkat persentase 62,79\%. Pada rentan usia 20-30 tahun sebanyak 16 orang dengan tingkat persentase $32,21 \%$. Hal ini dapat disimpulkan bahwa manajer hotel bintang 3 dan bintang 4 yang berada di kota Kendari mayoritas berada pada usia produktif.

\section{Karakteristik Responden Berdasarkan Jenis Kelamin}

Hasil penelitian yang dilakukan pada 14 responden yakni manajer hotel bintang 3 dan bintang 4 yang berada di kota Kendari menunjukkan bahwa 43 manajer hotel bintang 3 dan bintang 4 yang berada di kota Kendari yang menjadi responden dalam penelitian ini, menunjukkan bahwa mayoritas responden berjenis kelamin laki-laki yaitu sebanyak 35 orang dengan tingkat persentase 81,40 dan sebanyak 8 orang berjenis kelamin perempuan dengan tingkat persentase $18,60 \%$.

\section{Uji Validitas dan Reliabilitas}

Adapun hasil pengujian validitas dan reliabilitas penelitian ini yang dilakukan dengan menggunakan bantuan program IBM Statistical Versi 16, menunjukkan bahwa hasil uji validitas dari seluruh instrument memiliki koefisien korelasi $(r)>0,30$ dan nilai signifikan dari seluruh instrument berada dibawah $\alpha=0,05$ atau dengan tingkat kepercayaan $95 \%$, sehingga dapat disimpulkan bahwa semua item pernyataan yang digunakan sebagai instrument dalam penelitian ini adalah valid. Kemudian hasil uji reliabilitas menunjukkan nilai koefisien alpha dari seluruh item pernyataan yang dijadikan sebagai instrument dalam riset ini masih berada di atas cut of value $\geq 0,60$ yang berarti semua item pernyataan yang digunakan adalah realiabel (dapat dipercaya keandalannya). Hasil uji validitas dan reliabilitas instrument penelitian dapat disimpulkan bahwa seluruh butir (item) pernyataan yang digunakan adalah valid dan reliabel atau dapat dikatakan kuesioner yang digunakan layak dijadikansebagai instrument untuk melakukan pengukuran setiap variabel.

\section{Deskripsi Variabel Penelitian}

Deskripsi variabel penelitian bertujuan untuk menginterpretasikan mengenai distribusi frekuensi jawaban responden dari data yang telah dikumpulkan. Dalam penelitian ini jawaban responden dikategorikan dalam lima kategori dengan menggunakan skala likert. Masing-masing skala mempunyai penilaian dari sangat negatif ke sangat positif yang dituangkan dalam pilihan jawaban kuesioner. Dalam memberikan makna penilaian secara empiris, variabel penelitian ini mengadopsi prinsip dari pembobotan yang dikemukakan oleh Solimun (2017). Penelitian ini menggunakan 2 (dua) variabel yang terdiri dari penerapan sistem informasi akuntansi manajemen sebagai variabel independen dan kinerja manajerial sebagai variabel dependen.

\section{Variabel Independen (Penerapan Informasi Akuntansi Manajemen)}

Variabel penerapan informasi akuntansi manajemen (X) dalam penelitian ini diukur dengan menggunakan 14 butir item pernyataan dari 2 indikator yang meliputi frekuensi laporan rutin (X1.1) dan frekuensi laporan tidak rutin $\left(\mathrm{X}_{1.2}\right)$. Berdasarkan distribusi jawaban 
untuk variabel penerapan informasi akuntansi manajemen dapat dijelaskan secara berurutan mulai dari rata-rata jawaban responden yang tertinggi sampai yang terendah sebagai berikut:

1. Untuk item pernyataan variabel penerapan informasi akuntansi manajemen rata-rata jawaban yang tertinggi yaitu indikator frekuensi laporan rutin (X1.1) dengan rata-rata 4,35 atau berada dalam kategori sangat baik. Hal ini dapat disimpulkan bahwa frekuensi laporan rutin seperti laporan posisi keuangan, laba rugi, laporan persedian dan laporan piutang dapat memberikan informasi yang akurat yang membantu seorang manajer dalam pengambilan keputusan yang dapat menigkatkan kinerja manajerial.

2. Untuk item pernyataan pada indikator frekuensi laporan tidak rutin (X1.2) berada dalam kategori sangat baik dengan rata-rata 4,33. Hal ini dapat disimpulkan bahwa frekuensi laporan tidak rutin seperti analisis pasar, analisis dampak inflasi dan analisis kekuatan pesaing dapat menunjang kinerja manajerial.

\section{Variabel Dependen (Kinerja Manajerial)}

Variabel kinerja manajerial (Y) dalam penelitian ini diukur dengan menggunakan 16 butir item pernyataan dari 8 indikator yang meliputi perencanaan $\left(\mathrm{Y}_{1.1}\right)$, investigasi $\left(\mathrm{Y}_{1.2}\right)$, koordinasi $\left(\mathrm{Y}_{1.3}\right)$, evaluasi $\left(\mathrm{Y}_{1.4}\right)$, pemilihan staf $\left(\mathrm{Y}_{1.5}\right)$, negosiasi $\left(\mathrm{Y}_{1.6}\right)$, pengawasan $\left(\mathrm{Y}_{1.7}\right)$ dan perwakilan $\left(\mathrm{Y}_{1.8}\right)$.

Berdasarkan distribusi jawaban untuk variabel kinerja manajerial dapat dijelaskan secara berurutan mulai dari rata-rata jawaban responden yang tertinggi sampai yang terendah sebagai berikut:

1. Untuk item pernyataan variabel kinerja manajerial rata-rata jawaban yang tertinggi yaitu indikator perencanaan (Y1.1) dengan rata-rata 4,50 atau berada dalam kategori sangat baik. Hal ini dapat disimpulkan bahwa seorang manajer yang dapat melakukan perencanaan operasi perusahaan yang baik maka dapat meningkatkan kienerjanya.

2. Untuk item pernyataan pada indikator pemilihan staf (Y1.5) berada dalam kategori sangat baik dengan rata-rata 4,44. Hal ini dapat disimpulkan bahwa seorang manajer harus memiliki kemampuan yang baik dalam melakukan perekrutan pegawai yang berkualitas agar dapat membantu meningkatkan kinerjanya.

3. Untuk item pernyataan pada indikator investigasi (Y1.2) berada dalam kategori sangat baik dengan rata-rata 4,43. Hal ini dapat disimpulkan bahwa seorang manajer harus mengumpulkan dan menyampaikan informasi berupa catatan atau laporan tepat pada waktunya agar dapat membantu meningkatkan kinerjanya.

4. Untuk item pernyataan pada indikator negosiasi (Y1.6) berada dalam kategori sangat baik dengan rata-rata 4,39. Hal ini dapat disimpulkan bahwa seorang manajer harus memiliki kemampuan bernegosiasi seperti kemampuan dalam melakukan pembelian, penjualan atau melakukan kontrak untuk barang dan jasa, menghubungi pemasok dan melakukan tawar menawar dengan penjual agar dapat membantu meningkatkan kinerjanya.

5. Untuk item pernyataan pada indikator pengawasan (Y1.7) berada dalam kategori sangat baik dengan rata-rata 4,39. Hal ini dapat disimpulkan bahwa seorang manajer harus memiliki kemampuan mengarahkan, memimpin, membimbing, melatih dan memberi penjelasan tentang peraturan kerja kepada bawahan dan mengawasi hasil kerja bawahan agar dapat membantu meningkatkan kinerjanya.

6. Untuk item pernyataan pada indikator perwakilan (Y1.8) berada dalam kategori sangat baik dengan rata-rata 4,39. Hal ini dapat disimpulkan bahwa seorang manejer harus memliki kemampuan dalam menghadiri pertemuan-pertemuan dengan perusahaan lain, pertemuan dengan perkumpulan bisnis, perwakilan dari organisasi, pidato untuk acaraacara kemasyarakatan, pendekatan ke masyarakat, serta kemampuan dalam 
mempromosikan tujuan utama perusahaan agar dapat membantu meningkatkan kinerjanya.

7. Untuk item pernyataan pada indikator evaluasi (Y1.4) berada dalam kategori sangat baik dengan rata-rata 4,33. Hal ini dapat disimpulkan bahwa seorang manejer harus memliki kemampuan dalam menilai dan mengukur kinerja yang diamati atau dilaporkan yang meliputi penilaian pegawai, penilaian catatan hasil, penilaian laporan keuangan, dan pemeriksaan produk agar dapat membantu meningkatkan kinerjanya.

8. Untuk item pernyataan pada indikator koordinasi (Y1.3) berada dalam kategori sangat baik dengan rata-rata 4,28. Hal ini dapat disimpulkan bahwa seorang manajer harus bekerjasama dengan bagian atau divisi lain untuk saling tukar informasi.agar dapat membantu meningkatkan kinerjanya.

\section{Uji Asumsi Klasik}

\section{Uji Autokorelasi}

Tujuan uji autokorelasi adalah untuk mengetahui apakah dalam sebuah model regresi linear ada korelasi antara kesalahan pengganggu pada periode $\mathrm{t}$ dengan kesalahan pada periode t-1 (sebelumnya). Jika terjadi korelasi, maka dinamakan ada problem autokorelasi. Tentu saja model regresi yang baik adalah regresi yang bebas dari autokorelasi. Untuk mendeteksi adanya autokorelasi bisa dilihat pada tabel D-W (DurbinWatson) yang bisa dijadikan patokan, sebagai berikut:

\section{Tabel 4.2}

Hasil Uji Autokorelasi

\begin{tabular}{|l|l|l|l|l|l|}
\hline Model & $\mathrm{R}$ & R Square & $\begin{array}{l}\text { Adjusted } \\
\text { Square }\end{array}$ & $\begin{array}{l}\text { Std. Error of the } \\
\text { Estimate }\end{array}$ & $\begin{array}{l}\text { Durbin- } \\
\text { Watson }\end{array}$ \\
\hline 1 & $.754^{\mathrm{a}}$ & .568 & .558 & 2.834 & 1.918 \\
\hline
\end{tabular}

a. Predictors: (Constant), Penerapan Informasi Akuntansi Manajemen

b. Dependent Variable: Kinerja Manajerial

Sumber : Hasil output IBM SPSS 16, data primer diolah tahun 2019

Berdasarkan output summary pada tabel 4.2, terlihat pada angka Durbin Watson (DW) adalah 1,918 dimana angka tersebut berada di antara -4 sampai +4 yang berarti tidak terjadi autokorelasi.

\section{Uji Normalitas}

Uji normalitas digunakan untuk mendeteksi apakah distribusi data variabel bebas dan variabel terikatnya adalah normal. Model regresi yang baik adalah mempunyai distribusi data normal atau mendekati normal. Untuk menguji normalitas ini diketahui dari tampilan grafik normal probability plot (P-P Plot Test) dan grafik histogram. Jika data menyebar di sekitar garis diagonal dan mengikuti arah garis diagonal, maka model regresi memenuhi asumsi normalitas. Jika data menyebar jauh dari garis diagonal dan/atau tidak mengikuti arah garis diagonal, maka model regresi tidak memenuhi asumsi normalitas.

\section{Gambar 4.1 Normal Probability Plot}

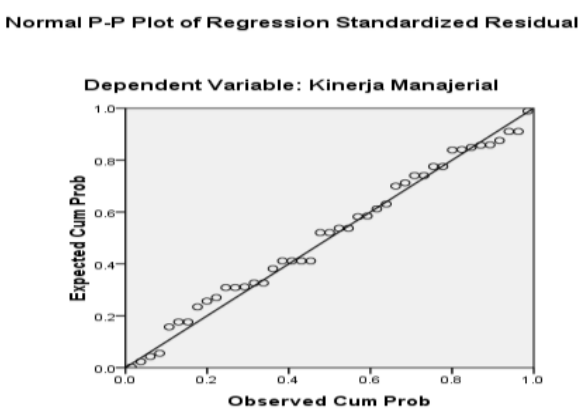


Berdasarkan gambar normal probability plot pada gambar 4.1, terdapat bahwa data menyebar di sekitar garis diagonal, serta penyebarannya mengikuti arah garis diagonal. Sehingga model regresi layak dipakai untuk prediksi dan telah memenuhi asumsi normalitas.

\section{Uji Heterokedastisitas}

Uji heterokedastisitas dilakukan melalui scatter plot (diagram pancar), dari variabel bebas terhadap variabel terikat terpenuhi jika diantara nilai residual dan nilai prediksinya tidak membentuk pola tertentu dan menjauhi angka skala 0. Hasil analisis data menunjukkan diagram pancar yang dihasilkan sebagai berikut:

\section{Gambar 4.2}

\section{Hasil Uji Heterokedastisitas}

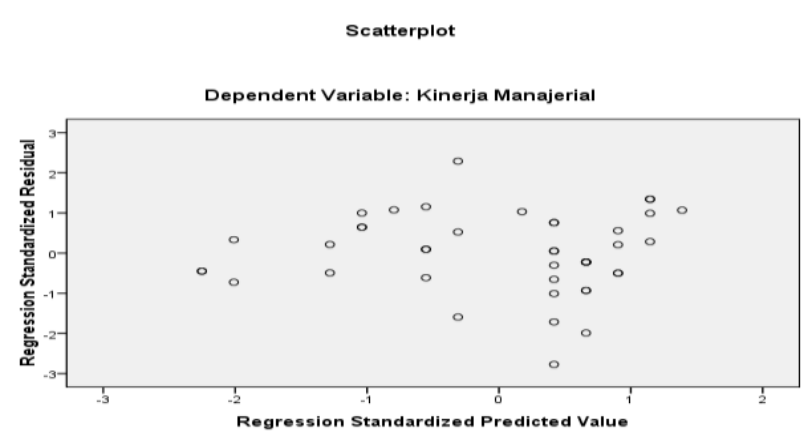

Berdasarkan gambar scatter plot 4.2, terlihat secara visual bahwa titik-titik menyebar secara acak (tidak membentuk pola yang jelas) dan tersebar baik diatas maupun dibawah angka 0 pada sumbu Y, sehingga dapat disimpulkan bahwa model regresi dalam penelitian ini terbebas dari masalah heteroskedastisitas.

\section{Hasil Pengujian Hipotesis}

Pengujian hipotesis dilakukan untuk membuktikan apakah variabel penerapan informasi akuntansi manajemen mempunyai pengaruh tehadap kinerja manajerial. Untuk membuktikan hal tersebut maka digunakan uji t sebagai berikut:

\section{Uji Parsial ( Uji t )}

Uji t pada dasarnya digunakan untuk menunjukkan seberapa jauh pengaruh satu variabel penjelas/independen secara individual dalam menerangkan variasi variabel dependen. Pengujian dilakukan dengan melihat taraf signifikansi ( $p$-value), jika taraf signifikansi yang dihasilkan dari perhitungan dibawah 0,05 maka hipotesis berpengaruh dan sebaliknya jika taraf signifikansi hasil lebih besar dari 0,05 maka hipotesis tidak berpengaruh. Hasil uji t dapat dilihat pada tabel berikut:

\section{Tabel 4.3}

Hasil Uji Parsial (Uji t)

\begin{tabular}{|c|c|c|c|c|c|}
\hline \multirow[t]{2}{*}{ Model } & \multicolumn{2}{|c|}{$\begin{array}{l}\text { Unstandardized } \\
\text { Coefficients }\end{array}$} & \multirow{2}{*}{ 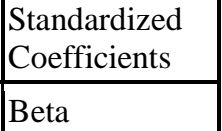 } & & \multirow[b]{2}{*}{ Sig. } \\
\hline & B & Std. Error & & & \\
\hline (Constant) & 21.495 & 6.413 & & 352 & .002 \\
\hline $\begin{array}{l}\text { Penerapan Informasi } \\
\text { Akuntansi Manajemen }\end{array}$ & 780 & .106 & .754 & .349 & .000 \\
\hline
\end{tabular}

a. Dependent Variable: Kinerja Manajerial

Sumber : Hasil output IBM SPSS 16, data primer diolah tahun 2019

Penerapan Informasi Akuntansi Manajemen (X) 
Berdasarkan hasil persamaan regresi yang pertama yaitu penerapan informasi akuntansi manajemen terhadap kinerja manajerial (Y), diperoleh nilai thitung untuk variabel penerapan informasi akuntansi manajemen adalah 7,349 pada signifikansi 0,000 dan nilai ttabel pada $\alpha=0,05$ adalah 2,020. Dengan demikian dapat diketahui bahwa thitung $>$ ttabel sehingga 7,349 $>2,020$ atau tingkat signifikan t sebesar $0,000<\alpha=0,05$. Nilai koefisien $\beta$ dari variabel $\mathrm{X}$ bernilai positif yaitu 0,780. Jadi hipotesis yang telah dirumuskan terbukti dan sesuai dengan hasil penelitian sehingga $\mathrm{H}_{1}$ dapat diterima. Hasil ini menunjukan bahwa penerapan informasi akuntansi manajemen berpengaruh signifikan terhadap kinerja manajerial, artinya semakin baik penerapan informasi akuntansi manajemen yang dilakukan maka semakin baik pula kinerja manajerial.

\section{Koefisien Determinasi $\left(\mathbf{R}^{2}\right)$}

Koefisien determinasi $\left(R^{2}\right)$ pada intinnya mengukur seberapa jauh kemampuan model dalam menerangkan variasi variabel dependen. Nilai koefisien determinasi berada diantara nol dan satu. Nilai $\left(R^{2}\right)$ yang kecil berarti kemampuan variabel-variabel independen dalam menjelaskan variabel dependen amat terbatas. Nilai yang mendekati satu berarti variabel-variabel independen memberikan hampir semua informasi yang dibutuhkan untuk memprediksi variabel-variabel dependen (Ghozali, 2016).

\section{Tabel 4.4}

\section{Koefisien Determinasi $\left(\mathbf{R}^{2}\right)$}

Model Summaryb

\begin{tabular}{|l|l|l|l|l|l|}
\hline Model & $\mathrm{R}$ & R Square & $\begin{array}{l}\text { Adjusted } \\
\text { Square }\end{array}$ & $\begin{array}{l}\text { Std. Error of the } \\
\text { Estimate }\end{array}$ & $\begin{array}{l}\text { Durbin- } \\
\text { Watson }\end{array}$ \\
\hline 1 & $.754^{\mathrm{a}}$ & .568 & .558 & 2.834 & 1.918 \\
\hline
\end{tabular}

a. Predictors: (Constant), Penerapan Informasi Akuntansi Manajemen

b. Dependent Variable: Kinerja Manajerial

Sumber : Hasil output IBM SPSS 16, data primer diolah tahun 2019

Hasil perhitungan statistik pada tabel 4.9, dapat diuraikan penjelasan sebagai berikut: Nilai $R$ Square sebesar 0,568 atau $56,80 \%$ yang memberikan arti bahwa variabel independen (penerapan informasi akuntansi manajemen) mempunyai pengaruh sebesar $56,80 \%$ terhadap variabel dependen (kinerja manajerial). Sedangkan, sisanya sebesar $43,20 \%$ dipengaruhi oleh faktor-faktor lain yang tidak dibahas dalam penelitian ini seperti keahlian, pengalaman dan lain-lain.

\section{Deskripsi Analisis Regresi Linear Sederhana}

Sebagaimana yang telah dikemukakan pada pembahasan sebelumnya bahwa untuk mengetahui pengaruh penerapan informasi akuntansi manajemen terhadap kinerja manajerial pada Hotel Kota Kendari Provinsi Sulawesi Tenggara, maka dilakukan analisis dengan metode statistik. Peralatan analisis statistik yang digunakan dalam penelitian ini adalah analisis regresi linear sederhana, selanjutnya pengolahan data dilakukan dengan menggunakan bantuan software IBM SPSS 16, kemudian di analisis dengan parameter yang telah dikemukakan dalam penelitian ini. Adapun hasil regresi dalam penelitian ini adalah sebagai berikut: 
Tabel 4.5

Deskripsi Analisis Regresi Linear Sederhana

\begin{tabular}{|c|c|c|c|c|c|c|c|}
\hline \multirow[b]{2}{*}{ Model } & \multicolumn{2}{|c|}{$\begin{array}{l}\text { Unstandardized } \\
\text { Coefficients }\end{array}$} & \multirow{2}{*}{\begin{tabular}{|r|}
$\begin{array}{l}\text { IStandardized } \\
\text { Coefficients }\end{array}$ \\
Beta \\
\end{tabular}} & & \multirow[b]{2}{*}{ sig. } & \multicolumn{2}{|c|}{$\begin{array}{l}\text { Collinearity } \\
\text { Statistics }\end{array}$} \\
\hline & B & $\begin{array}{c}\text { td. } \\
\text { Error }\end{array}$ & & & & Tolerance & IF \\
\hline (Constant) & 21.495 & .413 & & .352 & 002 & & \\
\hline $\begin{array}{l}\text { Penerapan Informasi } \\
\text { Akuntansi Manajemen }\end{array}$ & .780 & 106 & .754 & .349 & 000 & 1.000 & .000 \\
\hline
\end{tabular}

a. Dependent Variable: Kinerja Manajerial

Sumber : Hasil output IBM SPSS 16, data primer diolah tahun 2019

Berdasarkan hasil koefisiesen regresi pada tabel 4.13, maka dapat diperoleh persamaan sebagai berikut:

$\mathbf{Y}=\mathbf{2 1 . 4 9 5}+\mathbf{0} . \mathbf{7 8 0}+€$

Dimana :

$\mathrm{Y} \quad=$ Kinerja Manajerial

$\mathrm{X}=$ Penerapan Informasi Akuntansi Manajemen

Berdasarkan model persamaan regresi linear sederhana tersebut dapat diuraikan sebagai berikut: $\mathbf{Y}=\mathbf{2 1 . 4 9 5}+\mathbf{0 . 7 8 0}+\boldsymbol{€}$ menggambarkan bahwa variabel penerapan informasi akuntansi manajemen (X) dalam model regresi tersebut dapat dinyatakan jika variabel independen berubah sebesar 1 (satu), maka perubahan variabel kinerja manajerial (Y) adalah sebesar nilai koefisien $(\beta)$ dari nilai variabel independen tersebut. Konstanta $(\alpha)$ sebesar 21,495 memberikan pengertian bahwa jika penerapan informasi akuntansi manajemen (X) tidak mengalami perubahan atau sama dengan nol (0) maka kinerja manajerial (Y) sebesar 21,495 satuan. Jika nilai $\beta 1$ yang merupakan koefisien regresi dari penerapan informasi akuntansi manajemen (X) sebesar 0,780 yang artinya mempunyai pengaruh positif terhadap variabel kinerja manajerial (Y), artinya bahwa jika variabel penerapan informasi akuntansi manajemen $(\mathrm{X})$ bertambah 1 satuan maka kinerja manajerial (Y) juga akan mengalami peningkatan sebesar 0,780.

\section{Pembahasan}

Tujuan dilakukan penelitian ini adalah untuk mempelajari hal-hal yang berkaitan dengan variabel penelitian sehingga diperoleh informasi mengenai pengaruh penerapan informasi akuntansi manajemen tehadap kinerja manajerial secara parsial.

Pengaruh Penerapan Informasi Akuntansi Manajemen Terhadap Kinerja Manajerial

Berdasarkan hasil analisis data bahwa penerapan informasi akuntansi manajemen

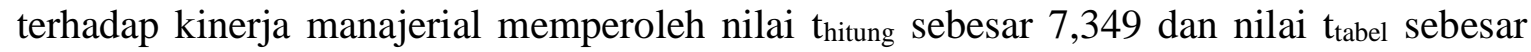
2,020. Hasil ini menunjukkan bahwa $t_{\text {hitung }}>\mathrm{t}_{\text {tabel}}$, hal ini berarti terdapat pengaruh penerapan informasi akuntansi manajemen terhadap kinerja manajerial. Selain itu nilai probabilitas sig nifikansi penerapan informasi akuntansi manajemen sebesar 0,000 dan lebih kecil dari 0,05 maka dapat dinyatakan bahwa penerapan informasi akuntansi manajemen berpengaruh signifikan terhadap kinerja manajerial. Bepengaruh singnifikan artiya semakin baik penerapan informasi akuntansi manajemen yang dilakukan maka semakin baik pula kinerja manajerial. Hasil uji koefisien determinasi $\left(\mathrm{R}^{2}\right)$ menunjukan bahwa kemampuan variabel penerapan informasi akuntansi manajemen dalam menjelaskan variabel kinerja manajerial yaitu sebesar 0,568 atau $56,80 \%$ dan sebesar $43,20 \%$ dipengaruhi oleh faktor-faktor lain yang tidak dibahas dalam penelitian ini seperti keahlian, pengalaman dan lain-lain. 
Berdasarkan distribusi jawaban responden yaitu manajer hotel bintang 3 dan bintang 4 yang berada di kota Kendari menunjukan bahwa indikator yang paling kuat memberikan kontribusi pada variabel penerapan informasi akuntansi manajemen yaitu indikator frekuensi laporan rutin dengan rata-rata jawaban responden sebesar 4,35 atau berada dalam kategori sangat baik. Hal ini dapat disimpulkan bahwa frekuensi laporan rutin seperti laporan posisi keuangan, laba rugi, laporan persedian dan laporan piutang dapat memberikan informasi yang akurat yang membantu seorang manajer dalam pengambilan keputusan yang dapat menigkatkan kinerja manajerial. Sedangkan indikator yang lain memberikan kontribusi pada variabel penerapan informasi akuntansi manajemen yaitu frekuensi laporan tidak rutin hal ini dapat disimpulkan bahwa frekuensi laporan tidak rutin seperti analisis pasar, analisis dampak inflasi dan analisis kekuatan pesaing dapat menunjang kinerja manajerial.

Frekuensi penerbitan laporan yang terdiri dari laporan rutin dan tidak rutin didefinisikan sebagai sejauh mana keterlibatan para manajer dalam mengevaluasi hasil operasional perusahaan sehari-hari (kinerja). Tanpa evaluasi ini manajer tidak akan tahu apakah tujuan yang diharapkan perusahaan sudah tercapai. Manajer akan mengevaluasi keberhasilan operasional secara harian, bulanan, per kawartal dan tahunan. Karena itu, untuk medapatkan keputusan yang tepat maka laporan akuntansi manajemen mempunyai syarat kualitas. Kualitas laporan bermaksud memberikan informasi tentang betapa pentingnya perhatian manajer dalam mengoptimalkan kinerja. Manajer akan mengevaluasi informasi operasional tersebut menjadi sebuah proses pengambilan keputusan, dalam pengambilan keputusan tersebtu membutuhkan informasi yang tidak hanya tersedia atau cukup, tetapi harus memiliki kualitas yang baik yaitu memiliki karakteristik akurat, relevan dan tepat waktu. Informasi yang mempunyai kualitas yang baik tersebut akan mendukung pengambilan keputusan, yang pada akhirnya akan mengarah kepada pencapaian kinerja perusahaan secara keseluruhan.

Laporan rutin biasanya dihasilkan dari sistem terstruktur yang diterbitkan secara berkala dan digunakan untuk pengendalian yang bersifat rutin, sedangkan laporan tidak rutin dihasilkan secara tidak terstruktur, biasanya bersifat analisis dan model- model keputusan. Laporan tersebut dibuat oleh bagian akuntansi dan diserahkan kepada manajemen puncak untuk mendukung pengambilan keputusan. Informasi akuntansi manajemen memerlukan berbagai bentuk informasi dalam bentuk laporan keuangan dan laporan non keuangan, berupa laporan rutin dan tidak rutin. Hal tersebut sejalan dengan pendapat Syamsi (2010) bahwa informasi akuntansi manajemen membutuhkan informasi berupa "laporan rutin/terstuktur dan laporan tidak rutin/tidak terstruktur yang digunakan manajer dalam mengambil keputusan.

Penerapan informasi akuntansi manajemen yang dilakukan oleh manajer hotel bintang 3 dan bintang 4 yang berada di kota Kendari sudah baik, hal ini dapat memberikan pengaruh signifikan terhadap kinerja manajerial. Hasil penelitian ini sejalan dengan penelitian yang dilakukan oleh Pamungkas (2016) dan Rahayu (2015) yang mengatakan bahwa penerapan informasi akuntansi manajemen berpengaruh signifikan terhadap kinerja manajerial.

\section{Kesimpulan}

\section{KESIMPULAN DAN SARAN}

Berdasarkan data yang diperoleh maupun hasil analisis yang telah dilakukan, maka dapat ditarik kesimpulan sesuai dengan hipotesis yang telah dirumuskan sebelumnya yaitu penerapan informasi akuntansi manajemen signifikan terhadap kinerja manajerial. Artinya 
Jurnal Akuntansi dan Keuangan (JAK)

Volume 6, No. 1 Februari Tahun 2021

Page: 279 - 291

http://ojs.uho.ac.id/index.php/jak-uho/issue/archive

e-ISSN: 2088-4656

semakin baik penerapan informasi akuntansi manajemen yang dilakukan oleh perusahaan maka semakin baik pula kinerja manajerial.

\section{Saran}

Berdasarkan kesimpulan yang telah diuraikan, penulis memberikan saran sebagai bahan pertimbangan dan sebagai bahan evaluasi sebagai berikut :

1. Hotel Kota Kendari Provinsi Sulawesi Tenggara diharapkan dapat memberikan informasi akuntansi yang berkualitas yang mendukung pengambilan keputusan manajer perusahaan agar tujuan yang ditetapkan dapat tercapai.

2. Bagi peneliti selanjutnya, dengan keterbatasan penulis agar dapat menambah variabelvariabel lain yang mungkin dapat membantu penelitian ini lebih baik khususnya mengenai kinerja manajerial, seperti pengalaman, pendidikan dan vaiabel-variabel lain yang mungkin berpengaruh kuat terhadap kinerja manajerial.

\section{DAFTAR PUSTAKA}

Fahmi, Irham. 2014. Analisis Laporan Keuangan. Bandung: Alfabeta.

Ghozali, Imam. 2016. Aplikasi Analisis Multivariate dengan Program IBM SPSS 23. Semarang: Badan Penerbit Universitas Diponegoro.

Hansen, Don R., dan Maryane M.Mowen. 2009. Akuntansi Manajerial. Edisi 8. Jakarta: Salemba Empat.

Ikatan Akuntan Indonesia. 2018. Pernyataan Standar Akuntansi Keuangan, PSAK No. 1. Jakarta : Ikatan Akuntan Indonesia.

Kasmir. 2015. Analisa Laporan Keuangan. Jakarta: Rajawali Pers.

Mulyadi. 2012. Akuntansi Manajemen Edisi ke-2. Yogyakarta: STIE YKPN.

Munawir, S. 2015. Analisa Laporan Keuangan. Jakarta: Salemba Empat.

Periansya. 2015. Analisa Laporan Keuangan. Palembang: Politeknik Negeri Sriwijaya.

Rudianto. 2013. Akuntansi Manajemen Informasi untuk Pengambilan Keputusan Strategis. Jakarta: Erlangga.

Silalahi, Ulber. 2011. Asas-Asas Manajemen. Bandung: Refika Aditama.

Simamora, Henry. 2012. Akuntansi Manajemen. Edisi Ketiga. Riau: Star Gate Publisher.

Siregar, Baldric dkk. 2013. Akuntansi Manajemen. Jakarta: Salemba Empat.

Siregar, Sofyan. 2013. Metode Penelitian Kuantitatif: Dilengkapi Perbandingan Perhitungan Manual \& SPSS Edisi Pertama. Jakarta: Prenada Media Group.

Sugiyono. 2015. Statistika Untuk Penelitian. Bandung: CV. Alfa Beta.

Sujarweni, Wiratna. 2015. Statistik Untuk Bisnis \& Ekonomi. Yogyakarta: Pustaka Baru Press.

Syamsi, Ibnu, S.U. 2010. Pengambilan Keputusan Dan Sistem Informasi. Cetakan Kedua, Jakarta : Bumi Aksara.

Wibowo. 2011. Manajemen Kinerja. Jakarta: Raja Grafindo Persada 